Esta revista forma parte del acervo de la Biblioteca Jurídica Virtual del Instituto de Investigaciones Jurídicas de la UNAM

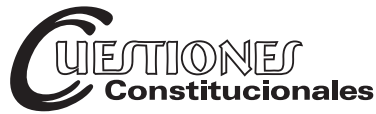

Revista Mexicana de Derecho Constitucional

Núm. 44, Enero-Junio 2021

ISSN (versión electrónica): 2448-4881

\title{
Los contornos constitucionales de la legítima defensa: A propósito de las acciones de inconstitucionalidad 1/2018 y 85/2017
}

\section{The constitutional contours of self-defense: Regarding the actions of unconstitutionality $1 / 2018$ and $85 / 2017$}

Recepción: 28 de febrero de 2020 Aceptación: 28 de julio de 2020

RESUMEN: La Suprema Corte se pronunció recientemente sobre la constitucionalidad de reformas a la legítima defensa efectuada por diversas entidades federativas en el caso mexicano, que explícitamente permiten la causación de daños tasados, incluyendo la muerte del agresor. La Suprema Corte concluyó que tales disposiciones resultan constitucionales. En el presente artículo se analizan los contornos constitucionales de la legítima defensa en la Carta Magna mexicana y se examina de forma crítica la resolución de la Suprema Corte. Se propone una postura alternativa que cuestiona la validez constitucional de tales normas.

\author{
Juan Luis GONZÁlEZ AlCÁNTARA* \\ Horacio VITE TORRES** \\ Mauro Arturo RIVERA LEÓN***
}

* Ministro de la Suprema Corte de Justicia de la Nación. Investigador honorario en el Instituto de Investigaciones Jurídicas de la UNAM. México. Correo electrónico: jlgonzalez@mail.scjn.gob.mx. Primer autor. ORCID: 0000-0002-6051-8034.

** Secretario de Estudio y Cuenta en la Suprema Corte de Justicia de la Nación. Funcionario de carrera judicial (18 años). Ha sido docente en la Universidad Nacional Autónoma de México y el Instituto de la Judicatura Federal. México. Correo electrónico: hvite@mail.scjn.gob.mx. Segundo autor. ORCID: 0000-0002-3079-4556.

*** Secretario de Estudio y Cuenta Adjunto en la Suprema Corte de Justicia de la Nación. Profesor en la Universidad Iberoamericana (SNI-I). México. Correo electrónico: arturo.riverale@gmail.com. Autor de correspondencia. ORCID: 0000-0003-4964-7086. 
Esta revista forma parte del acervo de la Biblioteca Jurídica Virtual del Instituto de Investigaciones Jurídicas de la UNAM

Palabras clave: derecho a la vida, legítima defensa, interpretación constitucional.
Keywords: right to life, self-defense, constitutional interpretation.

\begin{abstract}
SUMARIO: I. Introducción. II. Excusas constitucionales: las acciones de inconstitucionalidad 1/2018 Y 85/2017. III. Hacia una interpretación constitucional de los contornos de la legitima defensa. IV. Conclusiones. V. Fuentes consultadas.
\end{abstract}

\title{
I. INTRODUCCIÓN
}

La legítima defensa es una figura compleja que ha desatado interesantes estudios en materia de dogmática penal. Al ser conceptualizada como una eximente de responsabilidad, justifica la realización de una conducta que, de otra manera, recibiría una sanción penal. El hecho de que el ordenamiento jurídico, en ciertos casos, permita el ejercicio de la fuerza por los individuos no es casual. Se ampara la realización de una conducta defensiva que es inherente al comportamiento del ser humano.

Sin embargo, el populismo penal puede entrever en la legítima defensa una oportunidad para desplazar el descontento social respecto de un clima generalizado de inseguridad. Al igual que ha ocurrido con otros aspectos en materia penal y procesal penal (delitos, sanciones o prisión preventiva), las figuras del derecho penal y procesal penal han sido con frecuencia empleadas como sustitutivos remediales de condiciones de inseguridad no controladas por el Estado. En este artículo analizaremos regulaciones de las Entidades Federativas de Nuevo León y Veracruz que expandieron el concepto de la legítima defensa y se estudiará críticamente la resolución emitida por la Suprema Corte respecto de tales normas.

Este estudio está organizado de la siguiente manera. En I) ofrecemos una introducción al objeto de estudio y metodología del presente artículo. En II) Se analizan las resoluciones emitidas por la Suprema Corte Mexicana en las acciones de inconstitucionalidad 1/2018 y 85/2017 que estudiaron la constitucionalidad de modificaciones relevantes al régimen de la legítima defensa. La sección III) contiene un estudio tanto de dogmática penal como del régimen constitucional de la legítima defensa. Se sostiene que la explicitación del daño causable al sujeto agresor no es conforme con un entendimiento de los límites constitucionales de la legítima de- 
Esta revista forma parte del acervo de la Biblioteca Jurídica Virtual del Instituto de Investigaciones Jurídicas de la UNAM

fensa. Finalmente, en IV) se concluye evidenciando los complejos retos de la desnaturalización de las eximentes de responsabilidad en un Estado democrático de derecho.

\section{EXCUSAS CONSTITUCIONALES ACCIONES DE INCONSTITUCIONALIDAD 1/2018 Y 85/2017}

El análisis de la jurisprudencia constitucional es siempre un catalizador fuerte para el estudio de determinadas temáticas. Con frecuencia, ciertos estudios doctrinales han sido motivados por sentencias emitidas por tribunales. En el presente caso, las acciones de inconstitucionalidad 1/2018 y $85 / 2017$ constituyen el punto de partida para un estudio que no ha sido emprendido en el caso mexicano: los anclajes y contornos constitucionales de la legítima defensa. Esta figura, que ha sido revisada extensamente desde la óptica de la dogmática penal, no ha recibido atención desde una perspectiva constitucional, por lo menos en el caso mexicano.

Las acciones de inconstitucionalidad fueron promovidas por la Comisión Nacional de los Derechos Humanos para cuestionar la constitucionalidad de los artículos 17, fracción III, último párrafo y 25, fracción III, segundo párrafo de los Códigos Penales de Nuevo León y Veracruz, respectivamente.

Ambas normas tienen elementos comunes. Particularmente, se reformaron las disposiciones atinentes a la legítima defensa privilegiada y se estableció el tipo de daño que podía ser causado y se precisaba que tal daño quedaría amparado por la presunción de legítima defensa. ${ }^{1}$ Un análisis somero de la normatividad permite constatar que, en realidad, no tales normas no modificaban per se los elementos de la legítima defensa ni sus condiciones fundamentales, sino se limitaban a explicitar el daño causable. Tales reformas, habían sido introducidas en complejos contextos de inseguridad como una reacción a la presión social.

La Comisión de los Derechos Humanos, empleando la legitimación conferida en el artículo 105 constitucional, promovió acciones de incons-

1 En efecto, en el caso de Nuevo León se establecía "Igual presunción salvo prueba en contrario, favorecerá al que causare cualquier daño, lesión o prive de la vida a otro, a quien encontrare dentro de su hogar (...)". Por su parte, Veracruz establecía que "Se presumirá la defensa legítima, salvo prueba en contrario, al causar un daño, lesión o incluso la privación de la vida, a quien...”. 
Esta revista forma parte del acervo de la Biblioteca Jurídica Virtual del Instituto de Investigaciones Jurídicas de la UNAM

titucionalidad en contra de tales medidas. La impugnación cuestionaba las normas sosteniendo que éstas posibilitaban la comisión de hechos antijurídicos desproporcionados. Es decir, el alegato principal de la accionante era que permiten un actuar excesivo por parte de los particulares al repeler la agresión. Ello, estimaba la Comisión, era contrario al derecho de seguridad jurídica, integridad personal y derecho a la vida. ${ }^{2}$

La Suprema Corte, siguiendo un uso consolidado, determinó resolver las acciones de inconstitucionalidad de forma sucesiva y ajustar ambas sentencias, esto es, resolverlos con la misma argumentación y sentido. La primera acción en ser analizada fue la acción de inconstitucionalidad $1 / 2018$. La diversa $85 / 2017^{3}$ fue ajustada al primer criterio establecido en la primera.

La Suprema Corte resolvió toralmente el asunto en sesión de 5 de noviembre de 2019 (AI 1/2018, respecto a la legislación de Veracruz). La resolución efectuó un estudio sobre los principios generales de la legítima defensa. La sentencia recalcó que la legítima defensa no es un instrumento que permita una justicia por parte de los particulares. Precisamente, para ello resulta necesario que esté provista de estándares jurídicos dado que, de lo contrario, la acción del particular no estaría acotada a un límite preciso.

Una vez sentado un parámetro genérico desde la dogmática penal, se refirió que la normativa en análisis pertenecía a la categoría de legítima defensa privilegiada, esto es, una presunción iuris tantum respecto a la acreditación de los elementos de dicha figura. En tal calidad, esta presunción podía ser desvirtuada por el Ministerio Público (Suprema Corte de Justicia de la Nación, 2019).

La Suprema Corte concluyó que una interpretación sistemática de la legítima defensa privilegiada implicaba leer la disposición impugnada al tenor de la regulación propia de la legítima defensa genérica (integrante requisitos de ésta a la hipótesis específica regulada). Por ello, el Pleno de la Corte determinó que la norma contenía los elementos fundamentales

2 Las demandas fueron compartidas digitalmente por la propia Comisión y pueden ser consultadas en https://bit.ly/3clfyOm y https://bit.ly/2V62xNt (última consulta 19 de febrero de 2020).

3 La acción de inconstitucionalidad 1/2018 tuvo como ponente al ministro Pérez Dayán, mientras que la acción de inconstitucionalidad 85/2017 al ministro González A1cántara Carrancá. Al resolverse la acción de inconstitucionalidad 1/2018 en primer orden, el Pleno de la Suprema Corte determinó ajustar el criterio de la diversa AI 85/2017 a la ya resuelta.

Cuestiones Constitucionales, Núm. 44, Enero-Junio 2021

ISSN: $2448-4881$ 
Esta revista forma parte del acervo de la Biblioteca Jurídica Virtual del Instituto de Investigaciones Jurídicas de la UNAM

de la legítima defensa, a saber: i) la existencia de una agresión actual o inminente sin derecho; 2) la ausencia de una provocación inmediata y suficiente por parte de quien repele la agresión y 3) el no empleo de un medio irracional para repeler la agresión de acuerdo con el criterio de necesidad.

La naturaleza pública ${ }^{4}$ de las discusiones de la Suprema Corte posibilita el conocimiento de la discusión en los asuntos ${ }^{5}$. En la discusión, el Ministro González Alcántara se pronunció en contra de la validez del precepto. Consideró, para ello, que en realidad únicamente se precisaban los daños facultativos que podía causar el sujeto, sin regular las causas de la presunción de legítima defensa. Por tanto, expresó que tal norma excluía la posibilidad de considerar alternativas no letales distintas. La misma postura planteó el ministro Franco González Salas al considerar que la norma introduce la excluyente respecto a la privación de la vida, sin generar un marco de referencia sobre cuáles casos se encuentran comprendidos por ella.

Una duda similar inicialmente planteó el ministro Laynez Potisek. Establecer explícitamente el daño que potencialmente puede ser causado, a su juicio, pareciera de manera implícita autorizar la producción de ese daño. Por su parte, el Ministro Zaldívar, al comienzo de su intervención, manifestó que la técnica legislativa del artículo era defectuosa y que por ello le generaba dudas la constitucionalidad de la norma. Más aún, argumentó que la dogmática penal, que era el argumento toral del proyecto, no representaba un parámetro de regularidad constitucional sobre el cual analizar la figura.

Las ministras Piña y Esquivel, así como los ministros Aguilar Morales y Pardo compartieron la constitucionalidad del artículo en sus intervenciones. A su juicio, una interpretación sistemática de la normativa permite entender que la privación de la vida debe darse sólo bajo el marco de proporcionalidad y necesidad adecuadas. A pesar de las dudas externadas, la mayoría de los ministros votaron a favor de la constitucionalidad de la norma. La sentencia fue aprobada por mayoría de siete $\operatorname{votos}^{6}$, únicamente

4 Existe disposición constitucional expresa en el artículo 94 constitucional, transmisión televisiva y versión taquigráfica de tales sesiones. Véase el certero análisis de Rafael Coello (2013: 1407).

5 Por ejemplo, la versión taquigráfica de la discusión de la acción de inconstitucionalidad 1/2018, disponible en: https://bit.ly/2Vassn0.

6 Votaron a favor las ministras Piña y Esquivel, así como los ministros Aguilar, Pardo, Laynez, Pérez Dayán y Zaldívar (este último se apartó de diversas consideraciones de la sentencia mayoritaria). 
Esta revista forma parte del acervo de la Biblioteca Jurídica Virtual del Instituto de Investigaciones Jurídicas de la UNAM

votando en contra los ministros González Alcántara y Franco González Salas. El Pleno determinó ajustar el criterio de la acción de inconstitucionalidad $85 / 2017$ a la ya resuelta por ser temas similares.

De lo relatado, puede observarse que la resolución del Tribunal Pleno tiene, al menos, dos aspectos problemáticos. En primer término, como efectivamente lo refirió en la discusión el ministro Zaldívar, la sentencia no construyó un parámetro constitucional para analizar la legítima defensa. Es decir, empleó los elementos clásicos de la dogmática penal, presuponiendo que el incumplimiento de tales elementos derivaría en la inconstitucionalidad de la norma y que, viceversa, de demostrarse que la norma atendía a un modelo "clásico" de legítima defensa, ello implicaría su constitucionalidad.

En segundo término, la Corte ignoró un aspecto clave en la discusión. Tanto la normativa de Veracruz, como la normativa de Nuevo León no añadieron nuevos modelos de legítima defensa, sino que habían precisado el tipo de daño causable. Es decir, no eran regulaciones que ex novo configuraran la legítima defensa, sino que únicamente habían buscado facilitar al ciudadano la comprensión de la magnitud del daño amparada por las normas. De tal suerte, en realidad, las modificaciones, bajo la interpretación adoptada por el tribunal pleno, privaba de sentido las reformas. Bajo el entendimiento del Pleno, las normas significaban exactamente lo mismo tanto antes como después de ser reformadas. Si el intérprete no debe distinguir dónde no lo ha hecho el legislador, a contrario sensu, donde el legislador ha distinguido, debería distinguirse máxime que legislador consideró tan relevante este aspecto que modificó la norma especialmente para añadir tal contenido normativo).

La Suprema Corte, que con frecuencia acude a las exposiciones de motivos y procesos legislativos para desentrañar la voluntad del legislador, fue silente en este aspecto. Las exposiciones de motivos claramente hacían alusión a la voluntad de los legisladores de garantizar a los ciudadanos, como respuesta a un problema sistemático de seguridad pública, el "derecho" a privar de la vida a un agresor en ciertas hipótesis.

En las líneas sucesivas ofreceremos una teoría propia acerca del parámetro de regularidad constitucional a la luz del cual debió analizarse la norma, así como los contornos de la dogmática penal que pueden ser incorporados al debate y concluiremos con una interpretación alternativa respecto a la inconstitucionalidad de tales numerales. 
Esta revista forma parte del acervo de la Biblioteca Jurídica Virtual del Instituto de Investigaciones Jurídicas de la UNAM

\section{HACIA UNA INTERPRETACIÓN CONSTITUCIONAL DE LOS CONTORNOS DE LA LEGÍTIMA DEFENSA}

\section{Tamiz para evaluar la legítima defensa}

A pesar de que la Constitución mexicana tiene una naturaleza regulatoria, ${ }^{7}$ naturalmente, no menciona los elementos que debe contener la legítima defensa. Es decir, no hay un estándar constitucionalmente ordenado respecto a cómo configurarla. Sin embargo, el concepto si está presente en la Constitución Federal. El artículo 10 constitucional establece que los ciudadanos tienen derecho a tener armas en su domicilio "para su seguridad y su legítima defensa". La mención no es accidental, aunque la mayoría de los estudios se hayan centrado en la faceta de permisión de armas del artículo y no en la legítima defensa como concepto constitucional. ${ }^{8}$ Ello es paradójico, pues el texto constitucional claramente configura el derecho de posesión de armas como instrumental y subordinado a una finalidad específica de relevancia constitucional (seguridad y legítima defensa) ${ }^{9}$.

La consagración constitucional de la legítima defensa data, por cierto, del propio texto original de la Constitución de 1917 que sólo ha sido reformado en dos ocasiones (1971 y 2019) con fines únicamente de precisión del tipo de armas permisibles. De hecho, el propio artículo 10 es una herencia del constitucionalismo de 1857 porque un contenido sustancialmente idéntico se consagraba en el mismo artículo de la Constitución antecedente. Por el contrario, las Constituciones de 1824 y 1836 no empleaban el concepto.

De la forma en que la Constitución emplea el concepto, es posible extraer dos conclusiones. En primer lugar, que la propia Constitución presupone la existencia de una legítima defensa porque la caracteriza con

7 La observación es común. Por ejemplo, Fix-Zamudio (1999: 201) y Rivera, M. A. (2017: 23-25).

8 Ejemplos de ello son Luquet (2006: 270-273) y Carbonell (2006: 411-421).

9 Análisis de Ramos Duarte, Rebeca (2013: 1723), “Artículo 10 constitucional. Derecho a la legítima defensa". Curiosamente Ramos titula su estudio aludiendo a un derecho a "legítima defensa", aunque con posterioridad su análisis se predique sobre la posesión de armas de fuego. En realidad, pocos académicos se han percatado de que el artículo contiene, al menos, dos conceptos distintos que deben ser analizados; por un lado, el derecho a la posesión de armas y, por el otro, la legítima defensa como fin respecto al cual se goza instrumentalmente del primero. 
Esta revista forma parte del acervo de la Biblioteca Jurídica Virtual del Instituto de Investigaciones Jurídicas de la UNAM

un concepto constitucional. Esto implica que debe ser posible dotar de contenido normativo a este precepto, pues la propia Constitución lo emplea como fin que instrumentaliza el derecho a la posesión de armas. En segundo lugar, es la propia Constitución la que da pie a emplear lugares específicos como entidades reforzadas de la legítima defensa al calificar el domicilio como un lugar propio, en donde la legítima defensa ampararía eventualmente el uso de armas.

A pesar de que las conclusiones hasta ahora destacados son relevantes en tanto dotan de un cariz constitucional a un concepto propio de la dogmática penal, no ofrecen mayores elementos para controlar potencialmente una configuración específica de legítima defensa. Pareciera, así, que debemos acudir a los derechos en juego que comúnmente justifican y, a su vez, son restringidos por la legítima defensa, a saber, el derecho a la vida y el derecho a la integridad personal.

\section{A. Derecho a la vida}

El derecho a la vida se encuentra protegido en nuestro orden constitucional. Esta protección deriva tanto del contenido de la propia Constitución General y de los tratados internacionales como de la interpretación que han adoptado diversos organismos internacionales sobre las reglas y principios constitucionales y convencionales que rigen este derecho humano.

La Constitución Federal mexicana reconoce el derecho a la vida en sus artículos 10., párrafos primero y tercero, y 29, párrafo segundo. En el artículo primero, se realiza una tutela genérica y se establece una remisión al parámetro internacional para integrar los derechos en el ordenamiento mexicano. Por su parte, el artículo 29, al establecer que el derecho a la vida no podrá ser objeto de suspensión, materialmente reconoce tal derecho. Aunado a lo anterior, el propio artículo 22 constitucional establece una prohibición a la pena de muerte.

Como corolario de dichos preceptos constitucionales se obtiene, por un lado, que todas las personas gozarán de los derechos humanos reconocidos en la Constitución y en los tratados internacionales de los que el Estado mexicano sea parte, así como la ineludible obligación de las autoridades de promover, respetar, proteger y garantizar esos derechos y, por otro, que la Ley Suprema reconoce a la vida como una prerrogativa fundamental. 
Esta revista forma parte del acervo de la Biblioteca Jurídica Virtual del Instituto de Investigaciones Jurídicas de la UNAM

Ahora bien, el Tribunal Pleno de la Suprema Corte de Justicia de la Nación, al resolver la acción de inconstitucionalidad 10/2000, determinó que la Constitución Federal tutela el derecho a la protección de la vida humana, sin el cual no cabe la existencia ni disfrute de los demás derechos. Posteriormente, en la tesis P. LXI/2010 (Pleno, 2011: 24), se precisó que el derecho a la vida impone al Estado una obligación compleja, en tanto que no sólo prohíbe la privación de la vida (que se traduce en una obligación negativa), sino que también exige que, a la luz de la obligación de garantizar el pleno, libre y efectivo ejercicio de los derechos humanos, se adopten medidas positivas para preservar ese derecho en el ámbito legislativo, judicial y administrativo.

En ese sentido, la jurisprudencia constitucional ha considerado que existe transgresión al derecho a la vida por parte del Estado no sólo cuando una persona es privada de ésta por un agente estatal, sino también cuando éste no adopta las medidas razonables y necesarias tendentes a Preservarla o minimizar su riesgo.

El derecho a la vida también encuentra reconocimiento en los tratados internacionales signados por nuestro país. ${ }^{10}$ Así, la Convención Americana sobre Derechos Humanos, dispone en su artículo 4 el reconocimiento directo del derecho a la vida. Al respecto, la Corte Interamericana de Derechos Humanos ha sostenido que tal derecho es un presupuesto para el goce de los demás derechos de la propia Convención. En el caso Artavia Murillo y otros vs. Costa Rica (Corte Interamericana de Derechos Humanos, 2021: 71), ${ }^{11}$ el tribunal supranacional consideró que el derecho a la vida es un derecho humano fundamental, cuyo goce pleno es un prerrequisito para el disfrute de todos los demás derechos humanos. De igual forma, se ha sostenido que los Estados tienen obligaciones positivas y negativas de garantía en torno a la vida (Corte Interamericana de Derechos Humanos, 2006). Ante el actuar de los agentes estatales, la Corte Interamericana ha sostenido que todo uso de la fuerza debe obedecer a los principios de proporcionalidad, necesidad y humanidad (Corte IDH, 2007b).

Una interpretación funcional de la propia Convención debe llevar a concluir que todo uso de la fuerza sancionado por el Estado (no necesariamente realizado por agentes estatales) debe obedecer a los mismos principios anteriormente mencionados. Ello tendría impacto consustancial

\footnotetext{
${ }^{10}$ Un breve análisis comparado en Carmona (2002: 71 y ss.).

11 Resulta de interés el análisis de Ruiz Miguel y Zúñiza (2014).
} 
Esta revista forma parte del acervo de la Biblioteca Jurídica Virtual del Instituto de Investigaciones Jurídicas de la UNAM

en la regulación de la legítima defensa, al ser sancionada por el Estado en su normativa penal. Esta responsabilidad indirecta (Ugarte, 2016: 43) ${ }^{12}$ ha sido sostenida por la Corte Interamericana desde el caso Velázquez Rodríguez vs. Honduras (Corte Interamericana de Derechos Humanos, 1989). A pesar de que la Corte Interamericana no ha tenido ocasión de pronunciarse sobre configuraciones laxas de legítima defensa, parece que su doctrina de la responsabilidad indirecta podría aplicar en el caso de normas emitidas por los Estados que faciliten privaciones de la vida por particulares de forma no proporcional.

Por otro lado, el artículo 6.1 del Pacto Internacional de Derechos Civiles y Políticos prevé la naturaleza inherente del derecho a la vida, la obligación de protección de ésta por la ley y la prohibición de privación arbitraria de la vida. El Comité de Derechos Humanos de la Organización de las Naciones Unidas, a través de la Observación General número 36, interpretó dicho precepto en el sentido de que los Estados parte tienen la obligación de abstenerse de conductas que den lugar a una privación arbitraria de la vida. También deben ejercer la debida diligencia para proteger la vida de las personas frente a privaciones causadas por personas o entidades cuya conducta no sea atribuible al Estado (confróntese respecto a la observación análoga al criterio de Velázquez Rodríguez).

Por otra parte, el propio Comité consideró que a pesar de que es inherente a todo ser humano, el derecho a la vida no es absoluto. Al establecer que la privación de la vida no debe ser arbitraria, el artículo 6o., párrafo 1, reconoce implícitamente que la privación de la vida puede, en algunos casos, no resultar arbitraria. Por ejemplo, el uso de la fuerza letal en defensa propia, bajo ciertas condiciones, no constituiría una privación arbitraria de la vida. Empero, incluso aquellas medidas excepcionales que comportan privaciones de la vida que no son, en sí mismas, arbitrarias deben ser aplicadas de tal manera que no terminen siéndolo. Así, el Comité argumentó que para no ser calificada de arbitraria en virtud del artículo 6o., la utilización de fuerza letal por parte de una persona que actúe en legítima defensa, o por parte de otra persona que salga en su defensa, debe resultar razonable y necesaria, subsidiaria a alternativas no letales y empleada en caso de que exista peligro de muerte o lesiones inminentes. El uso deliberado de

12 Misma postura en Ayala y Rivero (2013: 116): la responsabilidad del Estado no sólo se configura "por la actuación directa de sus agentes sino cuando han actuado terceros (particular) con el apoyo, tolerancia u omisión del Estado".

Cuestiones Constitucionales, Núm. 44, Enero-Junio 2021

ISSN: $2448-4881$ 
Esta revista forma parte del acervo de la Biblioteca Jurídica Virtual del Instituto de Investigaciones Jurídicas de la UNAM

fuerza potencialmente letal para mantener el orden frente a amenazas que no revistan extrema gravedad, por ejemplo, para proteger la propiedad privada o impedir la fuga de un presunto delincuente o de un recluso que no suponga una amenaza grave e inminente para la vida o la integridad física de terceros, no puede considerarse un uso proporcionado de la fuerza.

\section{B. Derecho a la integridad personal}

Uno de los derechos que tiene incidencia en las conductas propias de la legítima defensa es el derecho a la integridad personal. La interrelación de tal derecho con el derecho a la vida es evidente. La Suprema Corte ha establecido que los derechos a la vida y a la integridad personal imponen al Estado tanto la obligación de que los agentes públicos y los particulares se abstengan de afectarlos (dimensión sustantiva), como la de prevenir, proteger y sancionar su posible afectación por parte de autoridades $\mathrm{y} / \mathrm{o}$ particulares (dimensión procesal). Es decir, tales derechos no sólo presuponen que ninguna persona sea privada de su vida arbitrariamente (obligación negativa), sino que además requieren que el Estado adopte todas las medidas apropiadas para preservarlos (obligación positiva), conforme al deber de garantizar su pleno y libre ejercicio. Así, la omisión de reprimir esas conductas abusivas se traduce en un quebrantamiento constitucional por inacción, injusticia para las víctimas e impunidad, lo cual lacera no sólo a la víctima de la violación de que se trate, sino también a la sociedad (Pleno, 2010: 27).

En el ámbito convencional, el artículo 5o. de la Convención Americana sobre Derechos Humanos, regula el derecho a la integridad personal, física, psíquica y moral. La Corte Interamericana de Derechos Humanos en diversos casos se ha pronunciado en torno al derecho a la integridad personal. Por ejemplo, al resolver el caso Cantoral Huamaní y García Santa Cruz vs. Perú (Corte Interamericana de Derechos Humanos, 2007a), la Corte apuntó que una de las condiciones para garantizar efectivamente los derechos a la vida, a la integridad y a la libertad personales es el cumplimiento del deber de investigar las afectaciones a los mismos, que se deriva del artículo 1.1 de la Convención en conjunto con el derecho sustantivo que debe ser amparado, protegido o garantizado.

A su vez, en el caso Norín Catrimán y otros (Dirigentes, miembros y activista del Pueblo Indígena Mapuche) vs. Chile (Corte Interamericana 
Esta revista forma parte del acervo de la Biblioteca Jurídica Virtual del Instituto de Investigaciones Jurídicas de la UNAM

de Derechos Humanos, 2014) la Corte estableció que la infracción del derecho a la integridad física y psíquica de las personas es una clase de violación que tiene diversas connotaciones de grado y que abarca desde la tortura hasta otro tipo de vejámenes o tratos crueles, inhumanos o degradantes, cuyas secuelas físicas y psíquicas varían de intensidad según los factores endógenos y exógenos que deberán ser demostrados en cada situación concreta. También al resolver el caso Masacre de Santo Domingo vs. Colombia (Corte Interamericana de Derechos Humanos, 2012), el tribunal supranacional consideró que la mera amenaza de que ocurra una conducta prohibida por el artículo 5o. de la Convención, cuando sea suficientemente real e inminente, puede en sí misma estar en conflicto con el derecho a la integridad personal.

Por su parte, el Pacto Internacional de Derechos Civiles y Políticos, en sus artículos 7o. y 9.1 establece un marco referencial para tales derechos. Estas disposiciones fueron objeto de interpretación por el Comité de Derechos Humanos de la Organización de las Naciones Unidas en diversas observaciones generales. Así, en la observación general núm. 20, expuso que la finalidad de las disposiciones del artículo 7o. del Pacto es proteger la dignidad y la integridad física y mental de la persona. El Estado Parte tiene el deber de brindar a toda persona, mediante medidas legislativas y de otra índole, la protección necesaria contra los actos prohibidos por el artículo 7o., sean infligidos por personas que actúen en el desempeño de sus funciones oficiales, al margen de dichas funciones o incluso a título privado.

Por su parte, en la observación general núm. 35, el Comité apuntó que el derecho a la seguridad personal protege a las personas contra lesiones físicas o psicológicas infligidas de manera intencionada, independientemente de que la víctima esté o no privada de libertad. El derecho a la seguridad personal también obliga a los Estados parte a adoptar medidas apropiadas ante amenazas de muerte contra personas del ámbito público $\mathrm{y}$, de manera más general, a proteger a las personas de amenazas previsibles contra su vida o su integridad física provenientes de cualquier agente estatal o privado. Los Estados parte deberán adoptar tanto medidas para prevenir lesiones futuras como medidas retrospectivas, como la aplicación de la legislación penal, en respuesta a lesiones ya infligidas. También deben prevenir el uso injustificado de la fuerza en las actividades de mantenimiento del orden público y ofrecer una reparación si tiene lugar, así 
Esta revista forma parte del acervo de la Biblioteca Jurídica Virtual del Instituto de Investigaciones Jurídicas de la UNAM

como proteger a la población contra abusos de las fuerzas de seguridad privadas y contra los riesgos a que da lugar la disponibilidad excesiva de armas de fuego.

\section{Las causas de justificación del delito}

En el contexto del derecho penal, el orden jurídico no se conforma únicamente de normas prohibitivas, sino también de preceptos permisivos que autorizan la realización de un hecho, en principio, prohibido. La existencia de un hecho típico implica que el actuar sea contrario a derecho. Sin embargo, existen supuestos en que el legislador permite la conducta típica cuando existen razones políticas, sociales y jurídicas que lo justifican. Estas conductas que prototípicamente resultarían prohibidas prima facie pero se encuentran permitidas o justificadas por el derecho, se denominan causas de justificación y constituyen el aspecto negativo de la antijuridicidad..$^{13}$ De esta manera, puede afirmarse que una conducta que esté amparada por una causa de justificación será, sin duda, conforme a derecho.

Bajo esta lógica, la justificación indica que un hecho genéricamente relevante para el derecho penal está autorizado por la ley. El permiso está asociado a la realización de la acción típica en determinadas circunstancias que se resumen en la concurrencia en el hecho típico de un interés: i) que entra en conflicto con el bien jurídicamente protegido por el tipo y ii) que la ley estima prevalente en el caso concreto respecto a este último. Cabe, por tanto, decir que el fundamento de la justificación de la conducta típica es la presencia de un «interés preponderante» (Obregón García y Gómez Lanz, 2015: 134).

El catálogo de las causas de justificación no es cerrado. Estos supuestos no son un problema específico del derecho penal, sino del ordenamiento jurídico en su conjunto. Así, las fuentes de las causas de justificación pueden tener su origen en cualquier rama del derecho que, por medio de sus disposiciones, autorice la realización de un hecho penalmente típico.

Conforme la doctrina (García Rivas, 2016: 238-244, y Muñoz Conde, 2004: 109-113), la justificación de un actuar típico no se sustenta exclusivamente en que se dé objetivamente la situación justificante, sino además,

13 Véase el debate atinente respecto a la colisión de intereses como elemento preponderante en las causas de justificación en Roxin (2016: 225). 
Esta revista forma parte del acervo de la Biblioteca Jurídica Virtual del Instituto de Investigaciones Jurídicas de la UNAM

es preciso que el autor conozca esa situación, incluso, que tenga las tendencias subjetivas especiales que exige la ley para justificar su acción. De acuerdo con esta concepción, las causas de justificación tienen elementos objetivos y subjetivos.

Los elementos objetivos pueden subdividirse en el presupuesto de la causa de justificación y las condiciones para la justificación. Respecto al presupuesto de la causa de justificación, debe recordarse que para que la conducta considerada típica no se considere prohibida, es necesario que la hubiera precedido una situación de amenaza a bienes jurídicos y que fuera ésta la que impulsara la acción lesiva del autor. De forma tal que el presupuesto de la causa de justificación deberá existir realmente cuando el hecho se ejecuta, no antes, no después. Por otro lado, en cuanto a las condiciones para la justificación, el legislador debe someter a condiciones de ejercicio estrictas el modo en que debe obrar el autor una vez detectada la presencia del presupuesto de la justificación. Las causas de justificación, por lo tanto, incluyen una serie de requisitos que debe cumplir el autor para ver autorizada su conducta.

En cuanto a la parte subjetiva, la justificación exige la concurrencia de un elemento subjetivo relativo a la voluntad de actuar justificadamente. La valoración que se haga de este elemento subjetivo dependerá del peso que esta vertiente de la causa de justificación tenga en cada concepción de esta. Para justificar una acción no es suficiente que el autor alcance un resultado objetivamente lícito, sino que es necesario que su voluntad se direccione hacia la obtención de ese resultado. El elemento subjetivo de justificación exige que el autor conozca y tenga la voluntad de actuar de un modo autorizado o permitido jurídicamente.

Por otro lado, la actualización de una causa de justificación tiene por efecto que la conducta no sea penalmente antijurídica, lo que implica, por tanto, que quien obra amparado por una causa de justificación no incurre en responsabilidad penal. De manera que una conducta exenta de responsabilidad criminal no podrá, en ningún caso, sancionarse ni siquiera con medidas de seguridad.

El examen sobre la actualización de alguna causa de justificación del delito corresponderá, incluso de manera oficiosa, al juez que conoce del conflicto penal con base en los datos o pruebas sometidos a su consideración. 
Esta revista forma parte del acervo de la Biblioteca Jurídica Virtual del Instituto de Investigaciones Jurídicas de la UNAM

\section{Hacia una teoría constitucional de la legítima defensa}

\section{A. Naturaleza y elementos de la legítima defensa conforme a la doctrina}

Como se ha dicho, la legítima defensa se reconoce como una causa de justificación del delito, es decir, la conducta típica se justifica quedando excluida la antijuridicidad y, por tanto, el delito. La legítima defensa se puede explicar mediante el "principio de protección" y el "principio del prevalecimiento del derecho". El agredido puede hacer todo lo necesario para protegerse; además, para afirmar la vigencia del Derecho en la sociedad, puede ejercer la legítima defensa incluso cuando no sería necesario para su protección (Roxin, 1997: 575).

Ahora bien, conforme a la moderna teoría del delito (Roxin, 1997: 611635; Zaffaroni, 2014: 609-630, Correa Flórez, 2017: 262-284, y Muñoz Conde, 2004: 120-124), se reconoce que la legítima defensa se configura por determinados elementos, los cuales son establecidos por el ordenamiento jurídico para evitar una definición arbitraria de los estándares de defensa creada por los propios gobernados. A continuación, se analizarán los elementos propios de la legítima defensa.

En primer término, debe estarse en presencia de una agresión actual e ilegítima (Parma, 2018: 561). La agresión es la amenaza de un bien jurídico por una conducta humana ya sea por acción u omisión. Esta agresión debe ser actual, lo que significa que se encuentre en curso su realización, cuando es inmediatamente inminente, está teniendo lugar o todavía prosigue, por lo que, no puede hablarse de legítima defensa cuando ha cesado la agresión o aún no ha comenzado. ${ }^{14}$ Además, la agresión debe ser ilegítima o antijurídica, esto es, requiere que se dé una efectiva puesta en peligro de los bienes jurídicos defendibles (Mañalich, 2013: 255).

Por su parte, en segundo término, son legítimamente defendibles todos los bienes jurídicos individuales, es decir, vida, integridad personal, salud, libertad, propiedad, custodia, honor, la morada, la personalidad, entre otros. Sobre este aspecto, no es necesario que los bienes estén protegidos por la norma penal para que sean objeto de legítima defensa, sino que

${ }^{14}$ Este supuesto es denominado defensa preventiva, la cual no se basa en una agresión, sino en una predicción. 
Esta revista forma parte del acervo de la Biblioteca Jurídica Virtual del Instituto de Investigaciones Jurídicas de la UNAM

pueden estar garantizados en otras legislaciones. Además, no solo son defendibles los bienes propios, sino también son los bienes de un tercero.

La necesidad racional de la defensa es un elemento fundamental. La necesidad impide que una situación sea distinta de lo que es, esto implica que si no existe alternativa el medio elegido es necesario (Correa, 2017: 275). Asimismo, necesaria es toda defensa idónea, que sea la más benigna dentro de varias clases de defensa elegibles y que no esté unida al riesgo inmediato de sufrir un daño. Bajo ese entendimiento, la persona que se defiende debe elegir, entre las clases de defensa posibles, la que cause el mínimo daño al agresor (Intini, 2005: 110).

El estándar que debe cumplir esta causa de justificación del delito es la necesidad racional de la defensa, para lo cual es preciso que la defensa llevada a cabo sea aquella que dentro de un catálogo de distintas posibles defensas, se elija la que cumpla con los siguientes elementos: $i$ ) que la defensa elegida sea objetivamente eficiente para repeler o hacer cesar la agresión, y ii) que dentro de las posibles defensas eficientes para hacer cesar la agresión, el agredido seleccione aquella que procure generar el menor daño posible al agresor (proporcionalidad de la respuesta). ${ }^{15}$

En relación con el segundo requisito, importa destacar que el principio del medio menos lesivo se ve relativizado por el hecho de que el agredido no tiene por qué correr ningún riesgo. Así, no está obligado a elegir una defensa de cuya eficacia dude. Sin embargo, dicha relativización no implica per se que el agredido pueda utilizar como defensa, en todos los casos, la privación de la vida del agresor al considerar que es el medio más eficiente, puesto que evita que el agredido corra el riesgo de sufrir un daño.

En estos términos, el agredido tiene la obligación de emplear, de manera progresiva, todos los medios de defensa que considere eficientes para hacer cesar la agresión. Lo que supone que el que se defiende debe primero utilizar, dentro de las posibles defensas plausibles para repelar la agresión, aquella que cause el menor daño al agresor y sólo cuando la defensa elegida resulte ineficiente, podrá utilizar la siguiente defensa que el agredido considere eficiente a pesar de que cause un mayor daño al agresor.

Por último, debe recordarse que la legítima defensa implica la falta de provocación suficiente por parte de quien se defiende. Para entender este

15 El tratamiento de la doctrina española ha sido interesante en este tema (STS de 20 de marzo de 1980) (Maza, 2007: 105).

Cuestiones Constitucionales, Núm. 44, Enero-Junio 2021

ISSN: $2448-4881$ 
Esta revista forma parte del acervo de la Biblioteca Jurídica Virtual del Instituto de Investigaciones Jurídicas de la UNAM

elemento debe partirse de la base de que sólo cuando la agresión sea la reacción normal a la provocación de que fue objeto el agresor se podrá denegar la legítima defensa ${ }^{16}$. Dicho en otras palabras, quien inicia una situación ilegítima de conflicto entre bienes, no podrá justificar sus conductas posteriores apelando a la legítima defensa. Es pues inaceptable la legítima defensa, cuando la agresión fue provocada intencionalmente para luego invocar legítima defensa, porque lejos de considerarse un derecho se trata de un abuso del derecho y de una manipulación del agresor.

Debe recordarse que la legítima defensa tiene como límite natural su exceso. Una conducta que afecta bienes jurídicos penales puede no ser antijurídica sólo si se encuentra dentro de los límites de la justificación. En cambio, si la actuación del agente excede esos límites, entonces su conducta, si bien contraria a derecho, debe sancionarse en función del exceso y no como si fuera un delito autónomo. De esta manera, habrá exceso en la legítima defensa cuando la conducta defensiva va más allá de lo necesario y racional, es decir, cuando la repulsa lícita de la agresión supera el umbral necesario para evitar el peligro que esta implica. Al respecto, tanto la doctrina como diversos ordenamientos jurídico-penales, reconocen que, al actualizarse un exceso en la defensa, la conducta debe sancionarse de acuerdo con los márgenes de punibilidad previstos para los delitos culposos.

Los anteriores elementos son considerados comúnmente en la configuración de la legítima defensa. Piénsese que ordenamientos jurídicos como Colombia (Ley 599, 2000: artículo 32), Argentina (Ley 11.179, 1984: artículo 34), España (Ley Orgánica 10/1995), e Italia (Codice Penale: artículo 52), al regular en sus legislaciones penales la figura de legítima defensa, incluyen los elementos enunciados en este apartado.

A partir de esta comparativa se obtiene, por un lado, que existe en la doctrina un consenso generalizado en cuanto al reconocimiento de los elementos necesarios que conforman la legítima defensa y, por otro, que las disposiciones que contemplen dicha figura deberán contener los elementos enunciados o al menos, no introducir otros elementos que contravengan esa figura.

16 No es accidental que autores como Schroeder hayan sostenido que "El problema de la provocación de la legítima defensa es también, en verdad, el problema de la escalada de la legítima defensa" (Schroeder, 2013: 164). 
Esta revista forma parte del acervo de la Biblioteca Jurídica Virtual del Instituto de Investigaciones Jurídicas de la UNAM

\section{B. Tratamiento jurisprudencial de la Suprema Corte}

La Suprema Corte, en su línea jurisprudencial, ha reconocido y analizado los diversos elementos que conforman la legítima defensa. El primero de ellos consiste en repeler una agresión. Esa acción de repeler debe ser dirigida al agresor y no a un tercero (Primera Sala, 1981: 108). El segundo elemento es la agresión definida como cualquier movimiento corporal del atacante que amenaza lesionar o lesiona intereses jurídicamente protegidos y que hace necesaria la objetividad de la violencia por parte de quien la rechaza (Apéndice de 2011: 149). El tercer elemento establece que la agresión debe ser real, es decir, que la acción desplegada indubitablemente entrañe la probabilidad real de lesionar los bienes jurídicos defendidos por el agredido (Primera Sala, 1966a: 19). En caso de que éste último no se cumpla, entonces se actualiza el supuesto de legítima defensa putativa, la cual consiste en que el supuesto agredido considera erróneamente la existencia de una agresión y realiza los actos de repulsa, sin estar consciente de la ilicitud de los mismos, al creer que actúa dentro del ejercicio de la excluyente de responsabilidad (Sala Auxiliar, 1987: 163).

La agresión debe ser actual o inminente, es decir, la defensa debe emplearse entre el momento en el cual el agresor comienza a realizar movimientos corporales con el fin de lastimar el interés jurídico protegido y el momento en el cual la agresión cesa por haber cumplido su objetivo o por haber sido repelida por una defensa inmediata. En caso de que la defensa no se realizare entre esos dos momentos, entonces no sería legítima, puesto que la agresión no era actual o inminente (Tribunales Colegiados de Circuito, 1987: 107). Finalmente, dicha agresión debe ser sin derecho, siendo requisitito que la conducta sea típica y antijurídica (Primera Sala 1966b: 45).

Otra característica fundamental de la legítima defensa es que esta puede ser empleada para proteger intereses jurídicos propios o de un tercero. Lo relevante es que la agresión suponga, necesariamente, una situación de peligro para la persona, honor o bienes ya sean propios o de un tercero al que se defiende (Primera Sala, 1965: 128).

Adicionalmente, la legítima defensa debe tomar en cuenta los criterios de necesidad y racionalidad de la defensa: el límite para juzgar la necesidad del medio empleado lo suministra la naturaleza o gravedad de la agresión y esto resultará en cada caso de una comparación no sólo de los 
Esta revista forma parte del acervo de la Biblioteca Jurídica Virtual del Instituto de Investigaciones Jurídicas de la UNAM

instrumentos usados, sino también de las condiciones personales del agresor y del agredido.

El juicio acerca de la necesidad y racionalidad del medio empleado debe ser exactamente concebido desde el punto de vista de un agredido razonable en el momento de la agresión, y no con la objetividad que puede consentir la reflexión ulterior. ${ }^{17}$

Por último, para actualizar el supuesto de legítima defensa es necesario que no medie provocación suficiente e inmediata. ${ }^{18}$ Lo anterior significa que si la provocación suficiente de una parte tiene como consecuencia inmediata la agresión de la otra, la primera no puede invocar legítima defensa para repeler dicha agresión.

Con base en lo anterior, es posible determinar que, un análisis puntual de la doctrina constitucional desarrollada por la Suprema Corte de Justicia de la Nación, nos conduce a estimar que la legítima defensa es una causa de justificación que excluye la responsabilidad adquirida al cometer un delito, siempre y cuando esa acción sea realizada con la intención de repeler una agresión real, actual o inminente y antijurídica; que atente contra los bienes jurídicos propios o de un tercero; que cumpla con los criterios de necesidad y racionalidad y que no medie provocación dolosa suficiente e inmediata.

\section{Legítima defensa privilegiada y su empleo en el derecho penal contemporáneo.}

La legítima defensa privilegiada es una institución del derecho penal sustantivo empleada por diversos países que busca paliar los efectos punitivos del proceso penal ante quien ha actuado en la causal de justificación de la legítima defensa (Rojo Araneda, 2013: 467).

El concepto de legítima defensa privilegiada no es reciente. Debemos recordar que el Código Penal Francés de 1810 ya hacía alusión a ella en su artículo $329 .{ }^{19} \mathrm{Sin}$ embargo, en tal concepción inicial la legítima defensa

17 Semanario Judicial de la Federación, Sexta Época, Vol. LIII, 2a. parte, p. 40, de rubro: "Legítima defensa. Justificación del medio empleado".

18 Semanario Judicial de la Federación, Séptima Época, Vol. 217-228, 2a. parte, p. 39, de rubro: "Legítima defensa, inmediatez de la provocación en la".

19 El artículo 329 era del tenor siguiente: "Sont compris dans les cas de nécessité actuelle de défense, les deux cas suivants:1o. Si l'homicide a été commis, si les blessures 
Esta revista forma parte del acervo de la Biblioteca Jurídica Virtual del Instituto de Investigaciones Jurídicas de la UNAM

privilegiada parecía constituirse como una causa de justificación per se y no como una presunción reforzada. ${ }^{20}$

La naturaleza de presunción de la legítima defensa privilegiada implica que ésta no es una subespecie específica de legítima defensa sino es una presunción de la concurrencia de los requisitos legales de dicho concepto previo a su potencial verificación. En ese sentido, es una presunción jurídica derrotable que se actualiza ante las circunstancias específicas del caso concreto como elemento atenuador sobre el individuo que puede tener el proceso penal en la etapa de verificación efectiva de la legítima defensa si no existiese la presunción establecida. ${ }^{21}$

En otras palabras, la presuposición sostenida por la legítima defensa privilegiada es una regla de interpretación de los hechos y del cúmulo probatorio ante circunstancias objetivamente valoradas por el legislador que revierten la balanza valorativa respecto a lo acontecido en un contexto específico. El detonante de la presunción, por lo general, es un elemento espacial o temporal (Garrido Montt, 2003: 136). Es decir, una locación específica (casa, departamento o residencia particular) o un momento temporal concreto (en la noche, por ejemplo). En ese sentido, si bien la actualización de las circunstancias previstas establece una presunción favorable al sujeto presuntamente defensor, ${ }^{22}$ no colaboran en la configuración de la causal de justificación (es decir, no pueden tornar en legítima defensa una agresión injustificada si el cúmulo probatorio es suficiente para revertir la presunción). ${ }^{23}$

Por tanto, los distintos elementos que la doctrina penal ha introducido para acotar la presunción tienen como finalidad distinguir las activida-

ont été faites, ou si les coups ont été portés en repoussant pendant la nuit l'escalade ou l'effraction des clôtures, murs ou entrée d'une maison ou d'un appartement habité ou de leurs dépendances; 20 . Si le fait a eu lieu en se défendant contre les auteurs de vols ou de pillages exécutés avec violence". Un análisis somero de la disposición puede encontrarse en Chauveau (1841: 126).

20 Ésta es, por cierto, la concepción de la moderna doctrina penal. En el mismo sentido Morin (1842: 249) (nuevamente sobre la disposición de 1810).

21 En Colombia se le ha denominado también "legítima defensa presunta". Cure rastrea los orígenes de su introducción al derecho colombiano, precisamente del derecho mexicano y argentino. Véase Cure (2010: 354).

22 Es decir, lo priva de la responsabilidad probatoria revirtiendo la carga de acreditación. Véase el análisis (respecto a la presunción francesa) de Elliott (2011: 113).

$23 \mathrm{O}$, en el caso polaco, si hay un exceso flagrante en la legítima defensa que permita revertir la presunción: Limburska (2018: 5).

Cuestiones Constitucionales, Núm. 44, Enero-Junio 2021

ISSN: $2448-4881$ 
Esta revista forma parte del acervo de la Biblioteca Jurídica Virtual del Instituto de Investigaciones Jurídicas de la UNAM

\section{des de defensa legítima a las represalias ilegítimas fuera de proporcio- nalidad. ${ }^{24}$}

Entre los países que emplean la figura de la legítima defensa privilegiada se encuentran Francia, ${ }^{25}$ Bélgica, ${ }^{26}$ Polonia, ${ }^{27}$ Argentina, ${ }^{28}$ Chile, ${ }^{29}$ inter alia.

Ahora bien, México ha empleado la figura tanto a nivel federal ${ }^{30}$ como en sus entidades federativas, a saber:

${ }^{24}$ Nuevamente, respecto al requisito polaco: Kluza (2018: 90).

25 Code Pénal, artículo 122-6: "Est présumé avoir agi en état de légitime défense celui qui accomplit l'acte 1o. Pour repousser, de nuit, l'entrée par effraction, violence ou ruse dans un lieu habité; $2^{\circ}$ Pour se défendre contre les auteurs de vols ou de pillages exécutés avec violence".

${ }^{26}$ Code Pénal Belgique, artículo 417: "Sont compris, dans les cas de nécessité actuelle de la défense, les deux cas suivants: Si l'homicide a été commis, si les blessures ont été faites, si les coups ont été portés en repoussant, pendant la nuit, l'escalade ou l'effraction des clôtures, murs ou entrées d'une maison ou d'un appartement habité ou de leurs dépendances, à moins qu'il soit établi que l'agent n'a pas pu croire à un attentat contre les personnes, soit comme but direct de celui qui tente l'escalade ou l'effraction, soit comme conséquence de la résistance que rencontreraient les desseins de celui-ci. Si le fait a eu lieu en se défendant contre les auteurs de vol ou de pillage, exécutés avec violence envers les personnes".

27 Kodeks Karny, artículo 25, §2a (reforma de 2018). "Nie podlega karze, kto przekracza granice obrony koniecznej, odpierając zamach polegający na wdarciu się do mieszkania, lokalu, domu albo na przylegający do nich ogrodzony teren lub odpierając zamach poprzedzony wdarciem się do tych miejsc, chyba że przekroczenie granic obrony koniecznej było rażące". (Es decir, establece una presunción que elimina la punibilidad a excepción de que se crucen los límites proporcionales del ejercicio de la legítima defensa (granic obrony).

28 Artículo 31, fracción sexta: El que obrare en defensa propia o de sus derechos, siempre que concurrieren las siguientes circunstancias... Se entenderá que concurren estas circunstancias respecto de aquel que durante la noche rechazare el escalamiento o fractura de los cercados, paredes o entradas de su casa, o departamento habitado o de sus dependencias, cualquiera que sea el daño ocasionado al agresor. Igualmente respecto de aquel que encontrare a un extraño dentro de su hogar, siempre que haya resistencia...".

29 Artículo 10, inciso sexto. "Se presumirá legalmente que concurren las circunstancias previstas en este número y en los números 4. y 5. precedentes, cualquiera que sea el daño que se ocasione al agresor; respecto de aquel que rechaza el escalamiento en los términos indicados en el número 1o. del artículo 440 de este Código, en una casa, departamento u oficina habitados, o en sus dependencias, o, si es de noche, en un local comercial o industrial y del que impida o trate de impedir la consumación de los delitos señalados en los artículos 141, 142, 361, 365, inciso segundo, 390, 391, 433 y 436 de este Código".

${ }^{30}$ Código Penal Federal (1931), artículo 15, fracción VI, segundo párrafo. 
Esta revista forma parte del acervo de la Biblioteca Jurídica Virtual del Instituto de Investigaciones Jurídicas de la UNAM

- Baja California ${ }^{31}$

- Campeche ${ }^{32}$

- Chiapas ${ }^{33}$

- Chihuahua ${ }^{34}$

- Ciudad de México ${ }^{35}$

- Durango ${ }^{36}$

- Estado de México ${ }^{37}$

- Guanajuato $^{38}$

- Guerrero $^{39}$

- Hidalgo $0^{40}$

- Jalisco $^{41}$

- Michoacán ${ }^{42}$

- Morelos ${ }^{43}$

31 Código Penal del Estado de Baja California (1989), artículo 23, fracción III, segundo párrafo (introduciendo, inclusive, la terminología "presunción de legítima defensa" y la posibilidad de establecer prueba en contrario).

32 Código Penal del Estado de Campeche (1996), artículo 33, sección B, fracción II, última porción normativa.

33 Código Penal para el Estado de Chiapas (1984), artículo 25, sección B, fracción II, segundo párrafo

34 Código Penal para el Estado de Chihuahua (1987), artículo 28, fracción IV, segundo párrafo.

35 Código Penal para el Distrito Federal (1931), artículo 29, sección B, Fracción I, párrafo II (que establece expresamente la naturaleza derrotable de la presunción).

${ }^{36}$ Código Penal para el Estado de Durango (1991), artículo 28, sección B, fracción II, párrafo II.

37 Código Penal para el Estado de México (1961), artículo 15, fracción III, inciso b, segundo párrafo (que establece la naturaleza derrotable de la presunción de forma expresa).

38 Código Penal para el Estado de Guanajuato (1972), artículo 33, fracción V, párrafo II (que establece también la naturaleza derrotable de la presunción.). Nótese que este párrafo fue adicionado por reforma del 24 de septiembre de 2018.

39 Código Penal para el Estado de Guerrero (1986), artículo 22, fracción III, segundo párrafo (que establece la naturaleza rebatible de la presunción).

40 Código Penal para el Estado de Hidalgo (1990), artículo 25, sección B), fracción II, segundo párrafo.

41 Código Penal para el Estado de Jalisco (1995), artículo 13, fracción III, inciso e, tercer párrafo (que establece expresamente la naturaleza de presunción, pero obliga al Ministerio Público a pronunciarse sobre la operatividad de la figura en cada caso).

42 Código Penal para el Estado de Michoacán (1980), artículo 27, fracción VI, segundo párrafo (que establece una naturaleza rebatible de la presunción expresa).

43 Código Penal para el Estado de Morelos (1996) artículo 23, fracción IV, segundo párrafo (que establece la naturaleza rebatible de la presunción). Nótese que en la expo-

Cuestiones Constitucionales, Núm. 44, Enero-Junio 2021

ISSN: $2448-4881$ 
Esta revista forma parte del acervo de la Biblioteca Jurídica Virtual del Instituto de Investigaciones Jurídicas de la UNAM

\begin{tabular}{|c|c|}
\hline- & Nayarit 44 \\
\hline- & Nuevo León ${ }^{45}$ \\
\hline- & Oaxaca $^{46}$ \\
\hline- & Puebla ${ }^{47}$ \\
\hline & Querétaro $^{48}$ \\
\hline & Quintana Roo ${ }^{49}$ \\
\hline & San Luis Potosín ${ }^{50}$ \\
\hline & Sinaloa ${ }^{51}$ \\
\hline- & Sonora $^{52}$ \\
\hline _ & Tabasco $^{53}$ \\
\hline & Tamaulipas $^{54}$ \\
\hline
\end{tabular}

sición de motivos del citado código expresamente se establece sobe dicha presunción que "en este punto se conserva, adecuadamente perfilada, la tradicional presunción de defensa, de carácter juris tantum, que implica una inversión en la carga de la prueba".

44 Código Penal para el Estado de Nayarit (1986), artículo 15, fracción III, inciso d), segundo párrafo (que regula las hipótesis en que opera la presunción, pero establece expresamente la sanción por el exceso en legítima defensa incluso en situaciones beneficiadas por tal presunción).

45 Impugnada en la AI 85/2017.

46 Código Penal para el Estado de Oaxaca (1980), artículo 14, sección B, fracción III, segundo párrafo (que regula la naturaleza rebatible de la presunción legal).

47 Código Penal para el Estado de Puebla (1986), artículo 26, fracción IV, inciso d, párrafos II y III (que establecen la naturaleza de presunción ante circunstancias específicas).

48 Código Penal para el Estado de Querétaro (1991), artículo 25, fracción II, segundo párrafo (estableciendo naturaleza de presunción rebatible por prueba en contrario. Nótese que específicamente este Código Penal denota la aplicación de la obligación de proporcionalidad aún ante la presunción).

49 Código Penal para el Estado de Quintana Roo, artículo 20, apartado B, fracción II, segundo párrafo.

50 Código Penal para el Estado de San Luis Potosí (2000), artículo 28, fracción IV, párrafo segundo (que establece la naturaleza rebatible de la legítima defensa por "prueba en contrario").

51 Código Penal para el Estado de Sinaloa (1992), artículo 26, fracción IV, sexto párrafo.

52 Código Penal para el Estado de Sonora (1994), artículo 13, apartado B, fracción II, segundo párrafo.

53 Código Penal para el Estado de Tabasco (1997), artículo 14, fracción IV, II párrafo (que establece que la presunción puede ser rebatida por prueba en contrario).

54 Código Penal para el Estado de Tamaulipas (2013), artículo 32, fracción II, párrafo sexto (que establece que la presunción puede ser rebatida por prueba en contrario). 
Esta revista forma parte del acervo de la Biblioteca Jurídica Virtual del Instituto de Investigaciones Jurídicas de la UNAM

- Tlaxcala ${ }^{55}$

- Veracruz ${ }^{56}$

- Yucatán ${ }^{57}$

- Zacatecas ${ }^{58}$

Es decir, dicha figura ha sido empleada por la totalidad de las entidades federativas y la propia Federación.

Por tanto, a nuestro juicio, la legítima defensa privilegiada o presupuesta, es una figura que opera, a nuestro juicio, con las siguientes características:

a) Establece una presunción jurídica derrotable de la actualización de una causa de justificación del delito y no es una causa de justificación ex novo;

b) Se actualiza ante la concurrencia de circunstancias especiales apreciadas por el legislador y regula el inicio de la presunción y no la magnitud de causación del daño;

c) Al ser una presunción derrotable, permite la punibilidad en caso de que excedan a la legítima defensa pues, aunque presuponga su acreditación, sanciona su exceso demostrable.

d) En su naturaleza de presunción, únicamente presupone valorativamente la acreditación de la causa de justificación, pero no modifica sus requisitos ni las limitantes de dicha causa.

En ese sentido, la doctrina penal ha valorado positivamente la inclusión de tales figuras en tanto facilita la legítima defensa real y atenúa los efectos negativos de sus procesos acreditatorios, siempre que se limite a efectos de no tutelar represiones desproporcionales (Kluza, 2018: 96).

Así, los distintos órdenes normativos mexicanos han empleado a la legítima defensa privilegiada como una forma de establecer por presunción la acreditación de requisitos legales, pero sin regular expresamente el daño párrafo.

55 Código Penal para el Estado de Tlaxcala (2009), artículo 28, fracción IV, segundo

56 Código Penal para el Estado de Veracruz (2007), artículo 25, fracción III, párrafo segundo. Impugnada en la AI 1/2018.

57 Código Penal para el Estado de Yucatán (2020), artículo 21, fracción II, segundo párrafo (que establece expresamente que la presunción es rebatible).

58 Código Penal para el Estado de Zacatecas (1986), artículo 13, fracción III, sexto párrafo (que establece que la presunción es rebatible por prueba en contrario).

Cuestiones Constitucionales, Núm. 44, Enero-Junio 2021

ISSN: $2448-4881$ 
Esta revista forma parte del acervo de la Biblioteca Jurídica Virtual del Instituto de Investigaciones Jurídicas de la UNAM

potencialmente a causar (lo que es objeto de un análisis de proporcionalidad de la actuación, a pesar de presuponer la concurrencia de los requisitos de la legítima defensa).

Es decir, el Código Penal Federal y los códigos de las diversas entidades federativas usualmente no regulan el daño causable y, con frecuencia, expresamente establecen tanto la derrotabilidad de la presunción como la aplicabilidad de la proporcionalidad de la intervención u obligaciones de indagar al Ministerio Público (Jalisco).

\section{D. ¿Realmente son constitucionales las normas que explicitan los daños en la legítima defensa?}

Los artículos 25, fracción III, inciso b) del Código Penal de Veracruz y 17, fracción III, último párrafo del Código Penal de Nuevo León comparte características similares. A saber, ambos artículos modifican la redacción propia de la presunción de legítima defensa de los respectivos códigos para añadir expresamente los posibles daños que pueden causarse al sujeto a su amparo. En el caso de Nuevo León, se alude a "lesión o prive de la vida a otro", mientras que, en el caso de Veracruz, se refiere a "lesión o incluso la privación de la vida".

Ahora bien, las normas concretamente impugnadas se ubican en supuestos relativos a la legítima defensa privilegiada. Añadieron, el tipo de daño que el sujeto que resiente la agresión puede causar durante el ejercicio de la legítima defensa.

Así, del contraste entre las disposiciones enunciadas y la doctrina de la legítima defensa enumerada, se aprecia que tales porciones normativas no constituyen una especie regulada de la legítima defensa privilegiada (figura que las normas regulan en secciones previas), pues destinan su objeto regulatorio a establecer la magnitud del daño causado en la legítima defensa y no solo a regular los elementos temporales o espaciales que activan la presunción.

En ese sentido, la defensa legítima privilegiada ya se encontraba instituida en el Código Penal de Veracruz y el de Nuevo León aún sin la inclusión de la especificación del daño (lesión/privación de la vida), porque existía una presunción de concurrencia de los elementos configurativos de la legítima defensa bajo ciertas condiciones. Sin embargo, la habilitación de privar de la vida o de lesionar, es un elemento normativo de segunda 
Esta revista forma parte del acervo de la Biblioteca Jurídica Virtual del Instituto de Investigaciones Jurídicas de la UNAM

grada que añade una descripción sobre los daños facultativos que puede causar el sujeto sin regular las causas de la presunción. El elemento anteriormente mencionado añadido específicamente por la porción normativa impugnada, no es compatible con la necesidad racional de la defensa y además excluye el análisis sobre el exceso en la legítima defensa.

En efecto, según se apuntó en el apartado que antecede, para examinar si existió necesidad racional en la defensa, se debe tener presente: i) que la defensa elegida se objetivamente eficiente para repeler o hacer cesar la agresión, y ii) que, dentro de las posibles defensas eficientes para hacer cesar la agresión, el agredido seleccione aquella que procure generar el menor daño posible al agresor.

En este sentido, las normas referidas no permiten apreciar la necesidad racional de la defensa, en la medida en que establece un margen de actuación muy amplio: la privación de la vida del agresor. De esta manera, se incentiva que el agredido no elija de manera objetiva la opción eficiente para repeler o hacer cesar la agresión, ya que su parámetro (o, en el peor de los casos, su objetivo) será la privación de la vida del intruso.

Las normas no contemplan como un criterio preferente la opción de generar el menor daño posible porque, de hecho, directamente le indican al ciudadano que, amparado por la presunción, se encuentra facultado para privar de la vida al atacante (por antonomasia, el mayor daño causable). En ese sentido, la intención de las normas es la desaparición del margen de apreciación en cuanto a determinar el posible exceso en la legítima defensa. Lo anterior es así, porque ante la expresión de la consecuencia lesiva más alta (privación de la vida) se inhibe la existencia de un parámetro para que se valore si el agredido, al repeler la agresión, excedió los límites de la legítima defensa.

Por tanto, a nuestro juicio, es debatible la conclusión constitucional alcanzada por la Suprema Corte, pues las normas analizadas parecen exceder los contornos de la legítima defensa para erigirse en fomento del ejercicio de un daño específico al agresor.

Sólo a modo de ejemplo, piénsese que la iniciativa de reforma en el caso de Nuevo León incluso parte de presuponer que la falta de mención del daño permisible a causar implica a ausencia de protección de tal acción con base en la legítima defensa ${ }^{59}$. Naturalmente, la afirmación resulta imprecisa

59 La iniciativa establece, textualmente: "Después de analizar el artículo 17 de Código Penal del Estado de Nuevo León, podemos observar que el último párrafo del presente 
Esta revista forma parte del acervo de la Biblioteca Jurídica Virtual del Instituto de Investigaciones Jurídicas de la UNAM

porque la presunción ya operaba en favor del ciudadano en caso de actualizarse las circunstancias enumeradas por la norma. Es decir, la propia adición normativa expresamente admitió tener por objeto únicamente señalar a los destinatarios de la norma (los ciudadanos) la magnitud del daño que se les permite causar dentro de la causa de justificación del delito.

El propio Dictamen de la Comisión de Justicia y Seguridad Pública del Congreso local expresamente estableció pretender prescindir de la necesidad de la defensa:

[L]a causa de exclusión del delito por presunción de legítima defensa según se expone de forma generalizada en la doctrina constituye una "legítima defensa privilegiada", es decir, que se basa en la condición de peligro implícito en determinados actos descritos por la ley y que prescinde de exigir la prueba de necesidad de defensa y la racionalidad de los medios empleados en ella; sin embargo esta presunción admite prueba en contrario, la cual corresponde, en todo caso, al Ministerio Público, quien deberá aportar los elementos necesarios para demostrar que la persona que produjo el daño no obró en legítima defensa.

Como puede observarse, el legislador local fue enfático al señalar que la presunción de legítima defensa no requiere acreditar la necesidad de defensa y la racionalidad de los medios empleados en ella. Este posicionamiento, sin embargo, más allá de constituir una justificación razonable para sustentar la figura en estudio, en realidad abona a la conclusión de que la institución jurídica regulada no cumple con los elementos necesarios que, conforme a la doctrina desarrollada, le dan sustento a la legítima defensa en el marco constitucional mexicano.

De hecho, la doctrina moderna al analizar disposiciones similares ha establecido que, cuando la propia configuración de la legítima defensa hace expresa referencia al daño causado, es más sensato considerarla como una simple regla de exclusión sin exigencias de proporcionalidad, que una inversión derrotable en la carga de la prueba (Wilenmann, 2017: 343). ${ }^{60}$ Por

artículo, que la presunción de legítima defensa limita «al que causare cualquier daño» sin mencionar «lesiones u homicidio», esto quiere decir que si alguien irrumpe tu hogar... al defender a tu persona o a las personas le causes algún tipo de lesión leves o graves o inclusive pierda la vida accidentalmente por algún golpe en el forcejeo, no estás jurídicamente protegido por el presente artículo".

60 De hecho, el análisis de Wilenmann se predica respecto a la legítima defensa privilegiada chilena, que tiene una formulación más moderada que la analizada por el Tribunal 
Esta revista forma parte del acervo de la Biblioteca Jurídica Virtual del Instituto de Investigaciones Jurídicas de la UNAM

ejemplo, Wilenmann considera que el argumento de presunción rebatible (empleado, por cierto, por el Pleno de la Corte) es débil y que, en su lugar, una norma que explicite el daño causable y lo englobe en una presunción comparte una naturaleza distinta.

Como afirma Wilenmann, este tipo de normas de cierta forma dan por satisfecho el requisito de necesidad de forma presupuesta e implica que gran cantidad de conductas abusivas sean cubiertas por la regla. De hecho, el análisis de Wilenmann fue practicado al tenor de la normativa chilena que únicamente habla de "daño" de modo abstracto. De manera que si la simple precisión de causar daño se estima incorrecta, tal conclusión robustece la propuesta en el presente estudio que analiza normas que directamente introducen como concepto la privación de la vida.

Lo anterior puede llevar a evidenciar que, contrario al criterio sostenido por la Suprema Corte, la norma debió declararse inconstitucional. La obligación del Estado mexicano respecto al derecho a la vida no implica únicamente abstenerse de su privación por agentes estatales, sino tampoco permitir la configuración laxa de eximentes de responsabilidad que fomenten su privación arbitraria.

Recordemos que si bien es cierto la legítima defensa se reconoce como una excepción al derecho a la vida (Stemler, 2010: 355; Fritze, 2004: 56; ;1 Bernsmann, 1992: 290, y Tórtora Aravena, 2009: 188-192), ${ }^{62}$ también lo es que, en palabras del Comité de Derechos Humanos:

debe resultar razonable y necesaria habida cuenta de la amenaza que supone el agresor; debe ser el último recurso tras agotarse o considerarse insuficientes las alternativas no letales, entre otras cosas las advertencias; la cantidad de fuerza aplicada no debe superar la estrictamente necesaria para responder a la amenaza; la fuerza aplicada debe ser cuidadosamente dirigida, en la medida de lo posible, únicamente contra el agresor; y la amenaza a la que se responde debe ser extrema, es decir, que exista peligro de muerte inminente o de lesiones graves.

El daño causado al agresor no puede estar determinado prima facie, sino que, por el contrario, debe ser de acuerdo con la necesidad racional

Pleno pues únicamente refiere genéricamente a "daño" y no explícitamente a privación de la vida.

61 Relativo a una limitación temporal del derecho.

62 Sobre la coexistencia de la legítima defensa frente a otros valores y principios constitucionales, véase Scherenberg (2009: 75).

Cuestiones Constitucionales, Núm. 44, Enero-Junio 2021

ISSN: 2448-4881 
Esta revista forma parte del acervo de la Biblioteca Jurídica Virtual del Instituto de Investigaciones Jurídicas de la UNAM

de la defensa empleada. Desde una perspectiva consecuencialista, la norma impugnada puede tener por efecto directo incentivar la comisión de un delito de alto impacto: el homicidio. Esto es así, porque si las normas introducen la permisión de privar de la vida, los ciudadanos tendrán claro que cuando una persona irrumpa en domicilios ajenos y ejerza violencia contra las personas o cosas, cuentan con la autorización de matarla, sin que exista necesidad de justificar que las condiciones en que se desarrolle la agresión tengan una vinculación con la inevitable defensa.

Además, paradójicamente, la ampliación de la legítima defensa lleva a un mayor peligro para la persona que sufre la agresión, no para el atacante. ${ }^{63}$ Las normas que alientan al ciudadano a la confrontación bajo la promesa de inmunidad, no toman en cuenta que el ciudadano promedio tiene menos experiencia en el uso de armas y el manejo de agresiones, por lo que alentarlo, es someterlo a un riesgo constante (Vigano, 2006: 2050).

En ese mismo contexto, las normas analizadas también conllevan en el agresor la condición subjetiva de que, una vez resuelto a delinquir e introducirse a un bien inmueble, sabedor de la posibilidad de ser privado de la vida, actúe en contra de los moradores de forma más violenta.

Ahora, nuestro análisis no implica que en ningún caso de legítima defensa pueda acontecer la privación de la vida del agresor. Aún en estos casos, la presunción establecida por la legítima defensa privilegiada obra a favor del ciudadano ante la concurrencia de los requisitos legales. Empero, la privación de la vida sigue siendo el último recurso al que debe recurrir la víctima, una vez descartadas las medidas alternativas posibles y las normas no deben alentarlo a actuar en sentido contrario. La privación de la vida es una consecuencia de la acción de defensa y no una necesidad que deba ser plasmada en el texto expreso de su configuración.

\section{CONCLUSIONES}

El presente artículo ha mostrado las problemáticas de configuración de normas que han establecido adiciones a la legítima defensa privilegiada. La extensión no natural de los contornos de la legítima defensa forma parte de una gama concreta de propuestas propias del populismo penal. El

${ }^{63}$ Similar observación ha hecho respecto al caso italiano Sotis (2019: 3), quien sostuvo: "ampliando i confini della legittima difesa si aumenta il pericolo per la vita e per l'incolumità fisica in primis delle vittime di una aggressione, non degli aggressori”. 
Esta revista forma parte del acervo de la Biblioteca Jurídica Virtual del Instituto de Investigaciones Jurídicas de la UNAM

aumento a altísimas penas de prisión, el uso de la prisión preventiva oficiosa, la rebaja de estándares probatorios y, claramente, una legítima defensa ampliamente configurada ${ }^{64}$ que tiende a la desproporción, son todas propuestas que pretenden darle al ciudadano una sensación falsa de seguridad ante la incapacidad de reacción del Estado. Trasladan las obligaciones del Estado a los particulares; ignoran las obligaciones de tutela en favor de configuraciones propias de la justicia popular y no del derecho penal.

En suma, las configuraciones de legítima defensa privilegiada que explicitan el daño causable no sólo tienen problemas de constitucionalidad en el caso mexicano, sino de diseño normativo. Esta problemática es compartida por los Códigos Penales de Veracruz y Nuevo León. Sus reformas no fueron inocuas, tuvieron por objeto prescindir de la proporcionalidad de la acción defensiva, aspecto que no se considera en el análisis de constitucionalidad evidenciado en la discusión de la Suprema Corte mexicana.

Ampliar los confines de la legítima defensa exponiendo al ciudadano abiertamente como posible la privación de la vida del atacante es una solución falsa. Se difuminan los límites del derecho a la vida del atacante y se incentiva al sujeto agredido a peligros propios que no son compensados por efecto disuasorio alguno.

Este tipo de configuraciones no son compatibles con el texto constitucional. Es el populismo penal en su expresión más clásica. Es el Estado claudicando de su deber de seguridad pública y regulando de forma que el particular obtenga satisfacción a sus pretensiones en un plano privado. Más que seguridad, es diferimiento; más que intervención directa, es abstención clara.

\section{FUENTES CONSULTADAS}

AA.VV. (2006). Derechos del Pueblo Mexicano. Tomo XVI. AA.VV. (1999). Hacia una nueva constitucionalidad. AA. VV. (2006). Studi in onore di Giorgio Marinucci. A cura di Emilio Dolcini e Carlo Enrico Paliero.

Apéndice de 2011, sexta época, t. III. Jurisprudencia 160, Legítima defensa. Concepto de agresión.

Ayala, Carlos y Rivero, María (2013). "Artículo 4. Derecho a la vida”.

64 También lo advierte Sánchez (2009: 12).

Cuestiones Constitucionales, Núm. 44, Enero-Junio 2021

ISSN: $2448-4881$ 
Esta revista forma parte del acervo de la Biblioteca Jurídica Virtual del Instituto de Investigaciones Jurídicas de la UNAM

BERNSMANN, K. (1992). Überlegungen zur tödlichen Notwehr bei nicht lebensbedrholichen Angriffen. Vol. 2. Núm. 104.

CARbonell, Miguel (2006). Artículo 10...

CARMONA, M. (2002). El derecho a la vida en la jurisprudencia de la Corte Interamericana de Derechos Humanos, núm. 42.

CoEllo, Rafael (2013). Artículo 94.

Chauveau, A. (1841). Théorie du Code Pénal, Revue de Législation et de Jurisprudence...

CORREA FlóREZ, M. (2017). Legítima defensa en situaciones sin confrontación: la muerte del tirano de casa...

CORREA, María Camila. (2017). Legítima defensa en situaciones sin confrontación: la muerte del tirano de casa...

Corte Interamericana de Derechos Humanos (2021). Excepciones preliminares, fondo, reparaciones y costas, Serie C. Núm. 257.

Corte Interamericana de Derechos Humanos (2007a). Sentencia de 10 de julio de 2007. Excepción preliminar, fondo, reparaciones y costas. Serie C. Núm. 167.

Corte IDH. (2007b). Caso Zambrano Vélez y otros vs. Ecuador. Fondo, reparaciones y costas. Serie C, núm. 166.

Corte Interamericana de Derechos Humanos. (1989). Caso Velásquez Rodríguez vs. Honduras. Reparaciones y costas. Serie C. Núm. 1.

Corte Interamericana de Derechos Humanos (2012). Sentencia de 30 de noviembre de 2012. Excepciones preliminares, fondo y reparaciones. Serie C. Núm. 259.

Corte Interamericana de Derechos Humanos (2014). Sentencia de 29 de mayo de 2014. Fondo, reparaciones y costas). Serie C. Núm. 279.

Cossío DíAz, J., (2017). Constitución Politica de los Estados Unidos Mexicanos Comentada. Tomo I.

CURE, Juan (2010). La ausencia de responsabilidad en el derecho penal.

Demetrio CRespo, E. y RodríGuez YaGÜE, C. (2016). Curso de derecho penal parte general

ElliotT, Catherine. (2011). French Criminal Law.

FERrer MAC-Gregor, Eduardo et al. (2003). Derechos Humanos en la Constitución: Comentarios de Jurisprudencia Constitucional e Interamericana. 
Esta revista forma parte del acervo de la Biblioteca Jurídica Virtual del Instituto de Investigaciones Jurídicas de la UNAM

FiX-ZAMUdiO, Héctor (1999). Hacia una nueva constitucionalidad. Necesidad de perfeccionar la reforma constitucional en el derecho mexicano...

FRITZE, L., (2004). Die Tötung Unschuldiger: Ein dogma auf dem prüfstand...

GARrido Montt, M. (2003). Derecho penal parte general. Tomo II.

GARCÍA RIVAS, Nicolás (2016). Las causas de justificación...

INTINI, Alberto. (2005). Legittima difesa, rischi di sproporzione quel genérico pericolo di agressione. Núm. 34, Año 5.

KALISZ, T., (2011). Prawo karne wykonawcze w systemie nauk kryminologicznych. Księga pamiatkowa ku czci Profesora Leszka Boguni

KLUZA, Jan. (2018). "Nowe Granice Obrony Koniecznej? Uwagi na tle Nowelizacji Kodesku Karnego z 8 Grudnia 2017 Roku”, Ruch Prawniczy, Ekonomiczny I Socjologiczny. Año LXXX. Núm. 3.

LiMBURSKA, Alicja. (2018). Niekaralność przekroczenia granic obrony koniecznej w świetle art. 25 § 2a k.k. Núm. 5.

LUQUET, Etienne (2006). Artículo 10...

MaÑAlich, Juan Pablo. (2013). Normas permisivas y deberes de tolerancia...

MAZA, José Manuel. (2007). Circunstancias que excluyen o modifican la responsabilidad criminal...

Morin, Acihlle (1842). Dictionnaire du Droit Criminel. París, Bureau du Journal du Droit Criminel.

MuÑoz CONDE, F. (2004). Teoría general del delito...

OBregón García, A. y Gómez LANZ, J. (2015). Derecho penal parte general: elementos básicos de teoría del delito, 2a. ed.

PARMA, C., (2018). Teoría del delito...

PAWLIK, M. (2013). La antijuricidad en el derecho penal...

SCJN, Pleno. (2011). Tesis P. LXI/2010. Semanario Judicial de la Federación y su Gaceta, Novena Época, t. XXXIII.

SCJN, Primera Sala (1965). Tesis 259235. Sexta Época. Vol. XXXVII, $2 a$. parte.

SCJN, Primera Sala (1966a). Tesis 259138. Vol. CIV, 2a. parte.

SCJN, Primera Sala (1966b). Tesis 803816. Vol. CXIV, 2a. parte. 
Esta revista forma parte del acervo de la Biblioteca Jurídica Virtual del Instituto de Investigaciones Jurídicas de la UNAM

SCJN, Primera Sala (1981), Tesis de registro 234665, vol. 145-150, 2 a. parte.

SCJN, Sala Auxiliar (1987). Tesis 245049. Vol. 217-218.

Rivera, M. A., (2017). Understanding Constitucional Amendments in Mexico. Vol. 9, núm. 2.

Rojo ArAnedA, M. (2013). La legítima defensa y la legítima defensa privilegiada. Vol. LXVI.

Roxin, C. (1997). Derecho penal parte general. Fundamentos. La estructura de la teoría del delito, 2a. ed.

Roxin, C. (2016). La teoría del delito en la discusión actual...

RuIZ Miguel, Alfonso y ZúÑIZA, Alejandra. (2014). Derecho a la vida y Constitución: Consecuencias de la Sentencia de la Corte Interamericana de Derechos Humanos Artavia Murillo vs. Costa Rica. Año 12. Núm. 1.

Corte Interamericana de Derechos Humanos (2006). Caso Montero Aranguren y otros (Retén de Catia) vs. Venezuela. Excepción preliminar, fondo, reparaciones y costas. Serie C. Núm. 150.

SÁNCHEZ, Fernando. (2009). Alarma social y derecho penal. InDret: Revista para el Análisis del Derecho. Núm. 1.

SCHERENBERG, Carl-Friedrich von (2009). Die Sozialethischen Einschränkungen der Notwehr...

SCHROEDER, Friedrich-Christian. (2013). Fundamentos y dogmática penal...

Sotis, Carlos. (2019). Il diritto penale tra scienza della sofferenza e sofferenze della scienza. Núm. 1.

SteIner, C. y URIBE, P. (2013), Convención Americana sobre Derechos Humanos Comentada...

STEMLER, P., (2010). Die Notwehr. Núm. 3.

Suprema Corte de Justicia de la Nación (2019). Sentencia de la acción inconstitucional 1/2018.

TÓRtORA AraVEnA, H. (2009). Las limitaciones constitucionales al derecho a la vida. Núm. 3.

Tribunales Colegiados de Circuito (1987). Tesis 246996. Vol. 121-126, 2a. parte. 
Esta revista forma parte del acervo de la Biblioteca Jurídica Virtual del Instituto de Investigaciones Jurídicas de la UNAM

UGARTE, Krúpskaya. (2016). La responsabilidad internacional de los Estados en materia de derechos humanos. Núm. 17. Año XIV.

SCHERENBERG, Carl-Friedrich von (2009). Die Sozialethischen Einschränkungen der Notwehr.

Vigano, F. (2006). Spunti per un Progetto Alternativo di Riforma della Legittima Difesa...

WilenManN, J. (2017). La justificación de un delito en situaciones de necesidad.

ZAFFARONI, Eugenio Raúl. (2014). Derecho penal parte general, 2a. ed. 